\title{
Interleukin-6 induces epithelial-mesenchymal transition in human intrahepatic biliary epithelial cells
}

\author{
GUI-XING JIANG ${ }^{1}$, LI-PING CAO ${ }^{1}$, PENG-CHENG KANG ${ }^{2}$, \\ XIANG-YU ZHONG ${ }^{2}$, TIAN-YU LIN ${ }^{1}$ and YUN-FU CUI ${ }^{2}$ \\ ${ }^{1}$ Department of Hepatopancreatobiliary Surgery, Sir Run Run Shaw Hospital, School of Medicine, \\ Zhejiang University, Hangzhou, Zhejiang 310000; ${ }^{2}$ Department of Hepatopancreatobiliary Surgery, \\ The Second Affiliated Hospital of Harbin Medical University, \\ Harbin, Heilongjiang 150086, P.R. China
}

Received December 23, 2014; Accepted October 5, 2015

DOI: $10.3892 / \mathrm{mmr} .2015 .4706$

\begin{abstract}
The aim of the present study was to determine the role of interleukin-6 (IL-6) in the epithelial-mesenchymal transition (EMT) of human intrahepatic biliary epithelial cell (HIBEC) lines in vitro. HIBECs were stimulated with IL-6 at concentrations of $0,10,20,50$ and $100 \mu \mathrm{g} / \mathrm{l}$ for $24 \mathrm{~h}$. A wound healing and Transwell assay were performed to determine the migratory and invasive capacity of HIBECs, respectively. Following $24 \mathrm{~h}$ of incubation, IL-6 at 10 and $20 \mu \mathrm{g} / 1$ significantly increased the number of migrated and invaded cells $(\mathrm{P}<0.05)$, while stimulation with 50 and $100 \mu \mathrm{g} / 1 \mathrm{IL}-6$ resulted in a further increase of the migratory and invasive capacity compared to that in all other groups $(\mathrm{P}<0.05)$. Furthermore, reverse-transcription quantitative polymerase chain reaction and western blot analyses were used to detect the mRNA and protein expression of EMT markers E-cadherin and vimentin in HIBECs. Decreased mRNA levels of E-cadherin accompanied by higher mRNA levels of vimentin were observed in the $10,20,50,100 \mu \mathrm{g} / 1 \mathrm{IL}-6$ groups compared to those in the $0 \mu \mathrm{g} / 1$ group (all $\mathrm{P}<0.05$ ). Furthermore, the protein expression of E-cadherin was decreased, while that of vimentin was increased in the 50 and $100 \mu \mathrm{g} / 1 \mathrm{IL}-6$ groups compared to those in the 0,10 and $20 \mu \mathrm{g} / 1 \mathrm{IL}-6$ groups (all $\mathrm{P}<0.05$ ). The present study therefore indicated that IL-6 promoted the process of EMT in HIBECs as characterized by increased migration and invasion of HIBECs and the typical changes in mRNA and protein expression of the EMT markers E-cadherin and vimentin.
\end{abstract}

Correspondence to: Dr Yun-Fu Cui, Department of Hepatopancreatobiliary Surgery, The Second Affiliated Hospital of Harbin Medical University, No. 246 Xuefu Road, Harbin, Heilongjiang 150086, P.R. China

E-mail: yfcui777@126.com

Key words: epithelial-mesenchymal transition, interleukin-6, human intrahepatic biliary epithelial cell, morphological changes, migration

\section{Introduction}

Epithelial-mesenchymal transition (EMT), the programmed conversion of epithelial into mesenchymal cells, is defined by a loss of epithelial-cell characteristics, including cell-cell adhesion, polarity and organized cytoskeleton (1). The EMT may be involved in several physiological functions and pathological conditions, including normal development, fibrosis and tumor metastasis, through signaling pathways activated by various stimuli (2-4). A previous study on the EMT in biliary epithelial cells (BECs) in advanced liver fibrosis reported cytoskeletal rearrangements during chronic liver injury, resulting in a mesenchymal phenotype (5). BECs, also known as cholangiocytes, are essential to the formation of bile components in the liver and effective transport of bile into the duodenum, although they comprise only 3-5\% of total cells in the normal liver $(6,7)$. BECs line the intra-hepatic biliary ducts, which are sites of damage in several diseases, including primary biliary cirrhosis and primary sclerosing cholangitis, and BECs may have active roles in the innate as well as the adaptive immune response by producing interleukin (IL)- 6 and IL-8 following injury (8-10).

IL-6 was identified as an important pleiotropic cytokine participating in acute inflammation, and previous molecular and pathological findings showed that intrahepatic BECs are able to synthesize IL-6, which is a critical mediator of the hepatic response to systemic inflammation $(11,12)$. It has been suggested that stimulation of human intrahepatic (HI) BECs with lipopolysaccharide resulted in increased secretion of IL-6 (8). In addition, previous studies suggested that IL-6 is a potent mitogen to BECs, and the growth of a cholangiocarcinoma cell line was attenuated by inhibition of IL-6-induced mitogen-mediated protein kinase activation, indicating a growth-regulatory function of IL-6 in HIBECs $(13,14)$. The EMT is associated with elevated E-cadherin and vimentin expression, as well as IL-6 production. Of note, IL-6 has been reported to be a potent inducer of the EMT in a number of tumor cell types (15-18). The present study aimed to identify factors regulating EMT in HIBECs, while a possible IL-6-mediated EMT in HIBECs has not yet been reported, to the best of our knowledge. Therefore, the effects of IL-6 stimulation on the 
EMT of HIBECs were assessed in vitro, and the underlying mechanisms were investigated.

\section{Materials and methods}

Cell culture. HIBEC lines (P5100) were purchased from ScienCell Research Laboratories (San Diego, CA, USA). All HIBEC lines were cultured in a humidified incubator at $37^{\circ} \mathrm{C}$ and $5 \% \mathrm{CO}_{2}$ and maintained in a mixture of Dulbecco's modified Eagle's medium (DMEM)/Ham's F12 (1:1) medium (Gibco; Thermo Fisher Scientific, Inc., Waltham, MA, USA) supplemented with $5 \%$ fetal bovine serum (FBS), $5 \mathrm{ng} / \mathrm{ml}$ epidermal growth factor, $0.4 \mu \mathrm{g} / \mathrm{ml}$ succinyl hydrocortisone, $2 \mathrm{nmol} / 1$ triiodothyronine, $5 \mu \mathrm{g} / \mathrm{ml}$ insulin and $10 \mu \mathrm{g} / \mathrm{ml}$ recombinant human hepatocyte growth factor (Gibco; Thermo Fisher Scientific, Inc.). Cells were passaged after a confluent monolayer was obtained; subsequently, cells at passage were detached with EDTA/trypsin (1:1;0.2\% each) for 5-8 min (Gibco; Thermo Fisher Scientific, Inc.,) and re-seeded in fresh culture medium. Cells were stained with hematoxylin-eosin (HE; Sigma-Aldrich, St. Louis, MO, USA) using a standard protocol (hematoxylin for $4 \mathrm{~min}$, rinsing with water, eosin for $30 \mathrm{sec}$ ) and observed under an Olympus IX83 microscope (Olympus Corporation, Tokyo, Japan).

Treatment groups. Based on the protocol of a previous study (19), HIBECs $\left(1 \times 10^{6}\right)$ were seeded in $10 \mathrm{~cm}$-diameter cell culture plates at a confluency of $80 \%$. Cells were then treated with various concentrations of IL- $6(0,10,20,50$ and $100 \mu \mathrm{g} / \mathrm{l}$; R\&D Systems Inc., Minneapolis, MN, USA). Cell-morphological changes were observed by inverse phase-contrast microscopy (Olympus CKX41; Olympus Corporation) after $24 \mathrm{~h}$ of stimulation.

Wound healing assay. Cell migration was assessed using a wound healing assay, which was performed based on a procedure described by Chun et al (19). HIBECs $\left(1.5 \times 10^{4}\right)$ were seeded in 24-well plates and cultured in DMEM, with three parallel wells for each experimental condition. Upon reaching confluence, the cell layers were vertically scratched using a Ziptip $\mu$-C18 (10- $\mu$ l) pipette tip (EMD Millipore, Billerica, MA, USA) and detached cells were removed by rinsing with phosphate-buffered saline (PBS). After $24 \mathrm{~h}$ of incubation with IL-6 $(0,10,2050$ and $100 \mu \mathrm{g} / \mathrm{l})$ in a volume of $1 \mathrm{ml}$, images were captured using an Olympus IX83 inverted microscope (Olympus Corporation). The number of cells migrated into the scratched region was counted and the assay was repeated three times, followed by semi-automated enumeration of the migrated cells (DotCount V1.2; Boston, MA, USA).

Transwell experiment. A Transwell invasion assay was performed in 24-well Transwell plates (Corning-Costar, Corning, NY, USA). The chambers were incubated with $3 \mu \mathrm{g} / \mathrm{ml}$ fibronectin at room temperature for $2 \mathrm{~h}$. After removing excess fibronectin, the chambers were washed with PBS twice and kept overnight at $4^{\circ} \mathrm{C}$. The cell suspension $(100 \mu \mathrm{l})$ was added to the chambers until the cell density was adjusted to $2 \times 10^{4} / \mathrm{ml}$, and cultured in serum-free DMEM/F12 medium. The chambers were placed in a 24-well plate, whereas $500 \mu 1 \mathrm{IL}-6(0,10,20$ 50 and $100 \mu \mathrm{g} / \mathrm{l})$ was added to the lower chamber, and cultured
Table I. Primers designed for reverse transcription-quantitative polymerase chain reaction.

\begin{tabular}{ll}
\hline Gene & \multicolumn{1}{c}{ Sequence } \\
\hline E-cadherin & F: 5'-GCCCCGCCTTATGATTCTCTGC-3' \\
& R: 5'-CTCGCCGCCTCCGTACATGTC-3' \\
Vimentin & F: 5'-CAGCAGTATGAAAGCGTGG-3' \\
& R: 5'-GGAAGAAAAGGTTGGCAGAG-3' \\
GAPDH & F: 5'-ACCCATCACCATCTTCCAGGAG-3' \\
& R: 5'-GAAGGGGCGGAGATGATGAC-3' \\
\hline
\end{tabular}

F, forward; R, reverse.

in $0.6 \mathrm{~mL}$ DMEM (high glucose) containing 10\% FBS. After $24 \mathrm{~h}$ of incubation, the cells that did not transgress through the membrane were removed using a cotton swab. The cells transgressed to the lower side of the membrane were fixed in $4 \%$ paraformaldehyde, stained with 4'6-diamidino-2-phenylindole dichlorhydrate (DAPI; Merck Millipore, Darmstadt, Germany) and counted in four randomly selected visual fields per well (magnification, x200). Three independent experiments were performed.

Reverse transcription-quantitative polymerase chain reaction $(R T-q P C R)$. The mRNA expression of E-cadherin and vimentin was determined by RT-qPCR according to the protocol of a previous study (15). Total RNA was extracted using a PCR kit (Takara Bio, Inc., Otsu, Japan) following the manufacturer's instructions. RNA enzyme-free ultrapure water (dilution, 1:10) and the absorbency at wavelengths of 260 and $280 \mathrm{~nm}$ were recorded using an ultraviolet spectrophotometer (UV-1100; Shanghai Mapada Instruments Co., Ltd., Shanghai, China) to determine purity and concentration. The RNA samples were extracted until an optical density (OD) 260/OD280 ratio of 1.7-2.1 was achieved. Complementary DNA synthesis was performed using the PrimeScript RT-PCR kit (Takara Bio, Inc., Otsu, Japan) based on the manufacturer's recommendations. RT 2 Real-Time SYBR Green (Takara Bio, Inc.) was used for real-time qPCR. GAPDH was used as an internal control. PCR primers were synthesized by Sangon Biotech Co., Ltd. (Shanghai, China), under the following reaction condition: $95^{\circ} \mathrm{C}$ pre-degeneration for $15 \mathrm{sec}, 95^{\circ} \mathrm{C}$ for $10 \mathrm{sec}, 58^{\circ} \mathrm{C}$ for $30 \mathrm{sec}$ and $72^{\circ} \mathrm{C}$ for $1 \mathrm{~min}$ ( 35 cycles in total). Primers used are listed in Table I. Results are expressed as the averaged of three independent experiments after normalization to GAPDH expression. The relative mRNA expression of E-cadherin and vimentin was calculated using the $2^{-\Delta \Delta \mathrm{Ct}}$ method (20).

Western blot analysis. After washing with PBS, cells were lysed in the dish with radioimmunoprecipitation assay buffer (EMD Millipore) for total protein extraction. Western blot analysis was performed with whole-cell lysates. The protein $(40 \mu \mathrm{g}$ per lane) was electrophoresed using Nu-Page gels (Invitrogen; Thermo Fisher Scientific, Inc.), electrotransferred onto polyvinylidene difluoride membranes (Invitrogen; Thermo Fisher Scientific, Inc.) over 90 min and blocked with PBS containing 


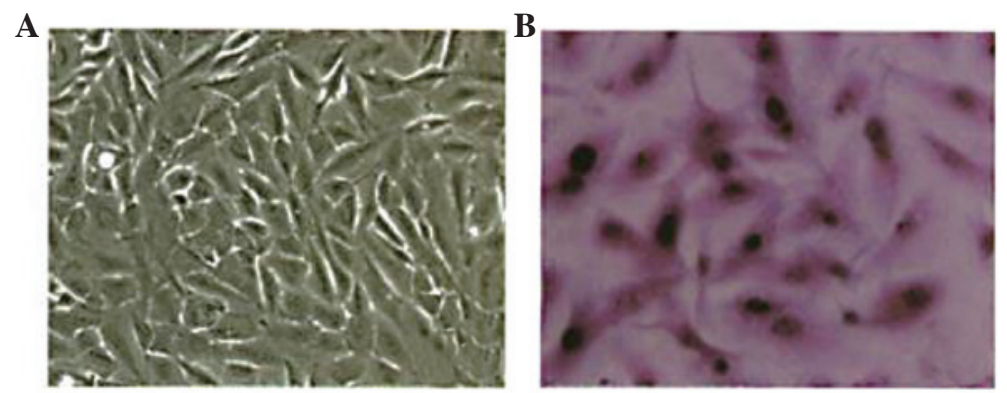

Figure 1. Morphology of HIBECs observed under an optical microscope prior to stimulation with interleukin-6. (A) Light microscopy image (magnification, x200); (B) hematoxylin-eosin-stained HIBECs (magnification, x200). HIBEC, human intrahepatic biliary epithelial cell.

A

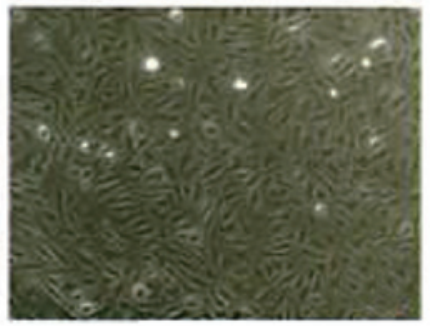

D

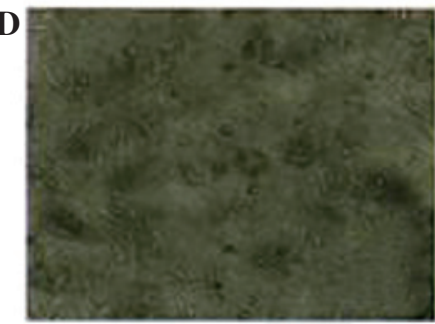

B

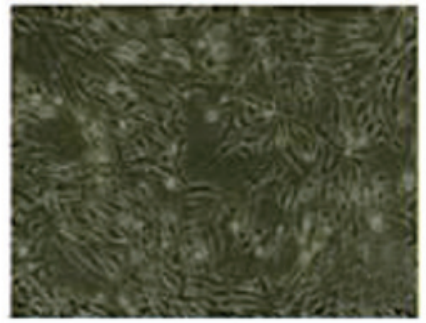

C

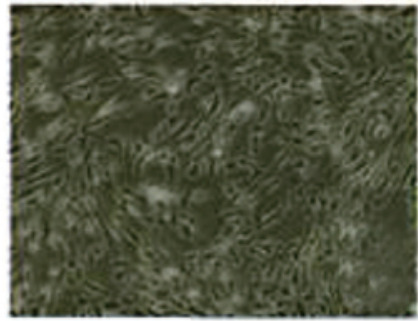

$\mathbf{E}$

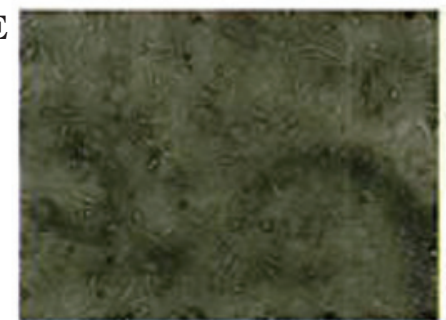

Figure 2. Morphology of human intrahepatic biliary epithelial cells exposed to interleukin- 6 at concentrations of (A) 0 , (B) 10 , (C) 20 , (D) 50 and (E) $100 \mu \mathrm{g} / 1$ for $24 \mathrm{~h}$ observed under an inverted phase contrast microscope (magnification, $\mathrm{x} 200$ ).

$5 \%$ dried skimmed milk for $1 \mathrm{~h}$. Rabbit anti-E-cadherin monoclonal antibody (1:500 dilution; cat. no. sc-7870; Santa Cruz Biotechnology, Inc., Santa Cruz, CA, USA) and anti-vimentin monoclonal antibody (1:1,000 dilution; cat. no. vim 3B4; Dako, Hamburg, Germany) were added as primary antibodies and incubated overnight at $4^{\circ} \mathrm{C}$. Subsequently, membranes were washed three times with Tris-buffered saline (Sigma-Aldrich), and the appropriate secondary antibodies labeled with horseradish peroxidase (Sigma-Aldrich) were added, followed by incubation at room temperature for $1 \mathrm{~h}$. Finally, the membranes were rinsed with PBS and Amersham ECL ${ }^{\mathrm{TM}}$ Advance Western Blotting Detection kit (GE Healthcare Life Sciences, Uppsala, Sweden) was added for visualization. Images of the blots were captured using a Gel Documentation 2000 system (Bio-Rad Laboratories, Inc. Hercules, CA, USA)and images were processed for densitometric quantification of the protein bands using ImageJ software (version 1.41; National Institutes of Health, Bethesda, MD, USA; http://imagej.nih.gov/ij). Each experimental condition was performed in triplicate.

Statistical analysis. All statistical analyses were performed using SPSS 17.0 software (SPSS, Inc., Chicago, IL, USA). All data were tested for normal distribution using the Shapiro-Wilk test. Values are expressed as the mean \pm standard deviation. Analysis of variance was applied for comparisons between different groups. $\mathrm{P}<0.05$ was considered to indicate a statistically significant difference.

\section{Results}

IL-6 induces morphological changes in HIBECs. The morphology of native HIBECs was short and fusiform or polygonal-shaped with clear, elliptical nuclei. Cells were closely packed with strong cell-cell adhesion and cell-matrix interactions (Figs. 1 and 2A). After $24 \mathrm{~h}$ of stimulation with IL-6 $(0,10,20,50$ or $100 \mu \mathrm{g} / \mathrm{l})$, HIBECs were observed to display reduced cell-cell adhesion and increased intercellular gaps (Fig. 2B-E, respectively). Obvious morphological changes were observed in HIBECs incubated with 50 and $100 \mu \mathrm{g} / 1$ IL-6 (Fig. 2D and E), which became long strips.

IL-6 enhances the cell-migratory and invasive capacity of HIBECs. A wound healing assay demonstrated that the number of cells migrated in the wounded area in the $0 \mu \mathrm{g} / \mathrm{l}$ IL-6 group $(109 \pm 18)$ was lower than that in the $10 \mu \mathrm{g} / 1$ (417 \pm 24$), 20 \mu \mathrm{g} / 1(434 \pm 22), 50 \mu \mathrm{g} / 1(508 \pm 31)$ and $100 \mu \mathrm{g} / 1$ $(517 \pm 28)$ IL-6 groups (all $\mathrm{P}<0.05)$. The number of migrated cells in the 50 and $100 \mu \mathrm{g} / 1$ groups was obviously increased compared with that in the 10 and $20 \mu \mathrm{g} / 1$ groups. However, no statistically significant differences in the number of migrated 


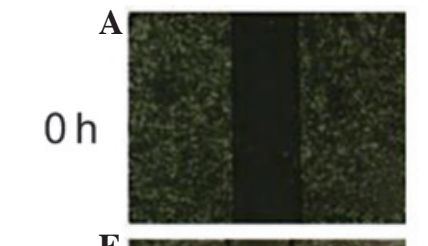

$24 \mathrm{~h}$

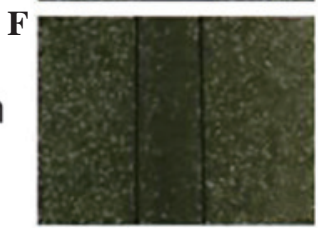

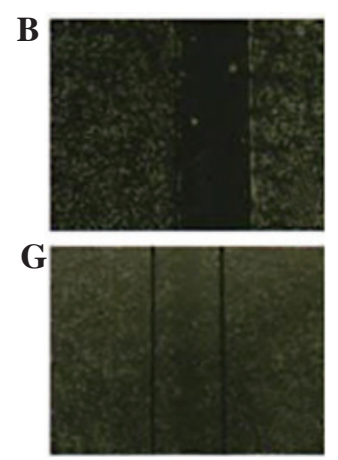
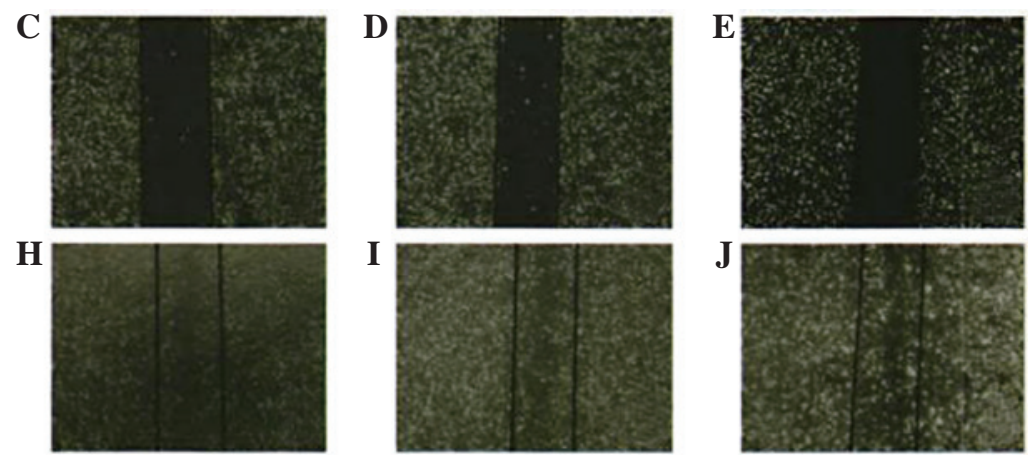

Figure 3. Migratory potential of human intrahepatic biliary epithelial cells after stimulation with IL-6. Inverted microscopy images of scratched cell monolayers subjected to the wound assay (magnification, $\mathrm{x} 40$ ). (A-E) cells at $0 \mathrm{~h}$ in the presence of $0,10,20,50$ and $100 \mu \mathrm{g} / 1 \mathrm{IL}-6$, respectively; (F-J) cells following incubation with $0,10,20,50$ and $100 \mu \mathrm{g} / 1 \mathrm{IL}-6$, respectively, for $24 \mathrm{~h}$. IL, interleukin-6.

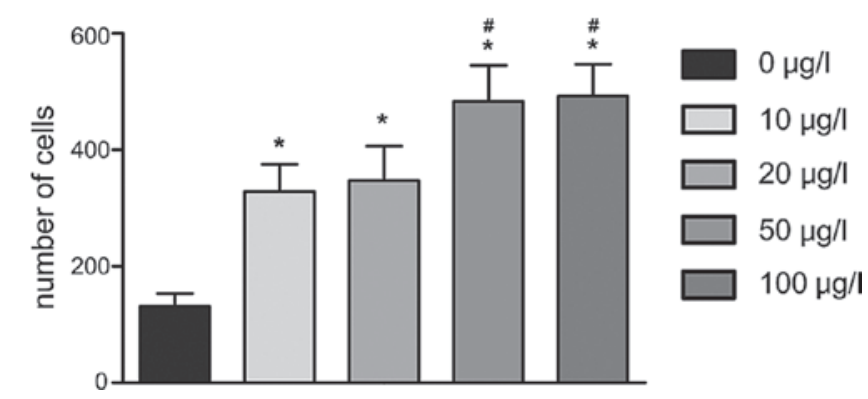

Figure 4. Number of cells migrated into the scratched region following incubation with interleukin-6 $(0,10,20,50$ or $100 \mu \mathrm{g} / \mathrm{l})$ for $24 \mathrm{~h}$. Values are expressed as the mean \pm standard deviation. ${ }^{*} \mathrm{P}<0.05$ vs. $0 \mu \mathrm{g} / 1 ;{ }^{*} \mathrm{P}<0.05$, vs. 10 and $20 \mu \mathrm{g} / 1$.

cells were observed between the 10 and $20 \mu \mathrm{g} / 1$ group or the 50 and $100 \mu \mathrm{g} / 1$ group (all $\mathrm{P}>0.05$ ) (Figs. 3 and 4).

Furthermore, a Transwell invasion assay demonstrated that cell number of cells transgressed through the membrane in the $0 \mu \mathrm{g} / 1$ IL- 6 group $(15 \pm 7)$ was lower than that in the $10 \mu \mathrm{g} / \mathrm{l}(85 \pm 11), 20 \mu \mathrm{g} / \mathrm{l}(90 \pm 14), 50 \mu \mathrm{g} / 1(121 \pm 13)$ and $100 \mu \mathrm{g} / 1(140 \pm 13) \mathrm{IL}-6$ groups following incubation for $24 \mathrm{~h}$ (all $\mathrm{P}<0.05$ ); furthermore, HIBECs stimulated with IL-6 at concentrations of 50 and $100 \mu \mathrm{g} / 1$ showed a significantly higher invasive capacity than those in the other groups $(\mathrm{P}<0.05)$ (Figs. 5 and 6).

IL-6 alters the expression of EMT-specific markers in HIBECs. The effects of IL-6 on the mRNA expression of E-cadherin, an epithelial cell marker, and vimentin, a mesenchymal cell marker, were assessed as indicators of the EMT of HIBECs using RT-qPCR (Table II; Fig. 7). Following treatment with IL-6 $(10,20,50$ or $100 \mu \mathrm{g} / \mathrm{l})$, the mRNA expression of E-cadherin was significantly decreased compared with that in the untreated group (all $\mathrm{P}<0.05$ ). By contrast, the mRNA expression of vimentin was significantly increased following treatment with IL-6 $(10,20,50$ or $100 \mu \mathrm{g} / 1)$ compared with that in untreated cells (all $\mathrm{P}<0.05$ ). In addition, the mRNA expression of E-cadherin the $50 \mu \mathrm{g} / 1 \mathrm{IL}-6$ group was significantly lower than that in the $20 \mu \mathrm{g} / 1 \mathrm{IL}-6$ group $(0.40 \pm 0.12$, vs. $0.80 \pm 0.09 ; \mathrm{P}=0.010)$, and the relative mRNA expression of vimentin in the $50 \mu \mathrm{g} / 1$ IL-6 group was significantly higher than that in the $20 \mu \mathrm{g} / 1$ group $(1.78 \pm 0.17$, vs. $1.43 \pm 0.15$; $\mathrm{P}=0.019$ ) (Fig. 7).
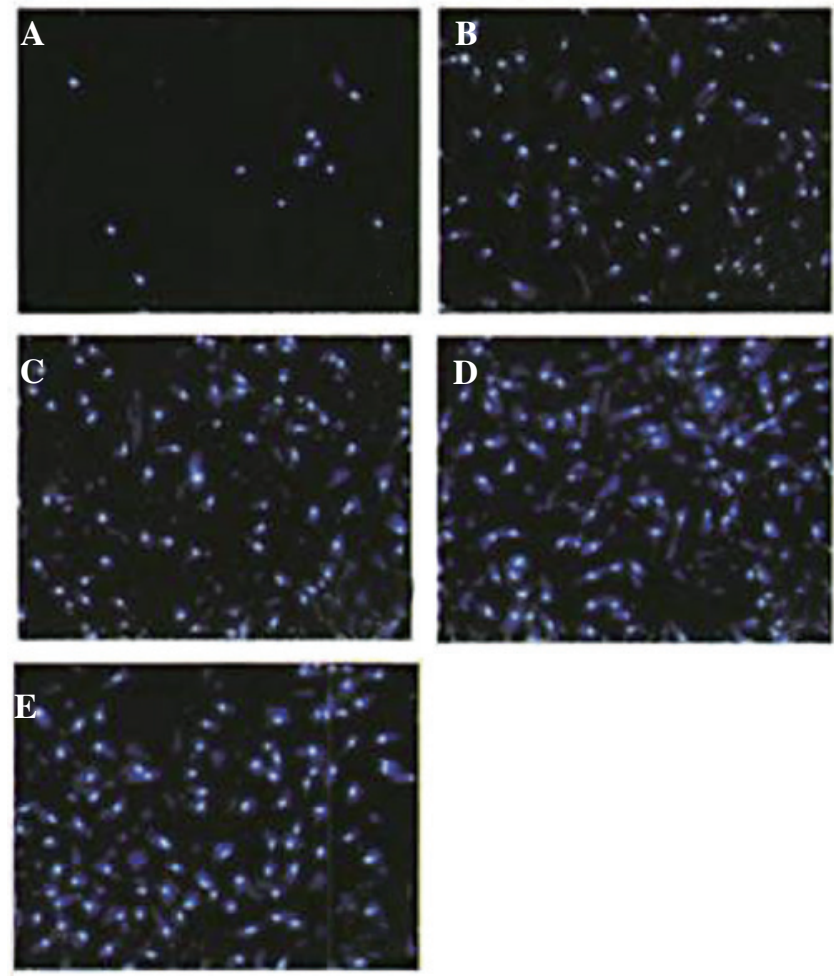

Figure 5. Effects of IL-6 on the invasive capacity of human intrahepatic biliary epithelial cells were assessed using a Transwell assay. Fluorescence microscopy images of cells which had transgressed to the lower side of the Transwell membranes (magnification, x200). Nuclei were stained with DAPI. Representative images of three experiments are shown. (A) $0 \mu \mathrm{g} / 1 \mathrm{IL}-6$ group; (B) $10 \mu \mathrm{g} / 1 \mathrm{IL}-6$ group; (C) $20 \mu \mathrm{g} / 1 \mathrm{IL}-6$ group; (D) $50 \mu \mathrm{g} / 1 \mathrm{IL}-6$ group; (E) $100 \mu \mathrm{g} / 1$ IL-6 group. IL, interleukin.

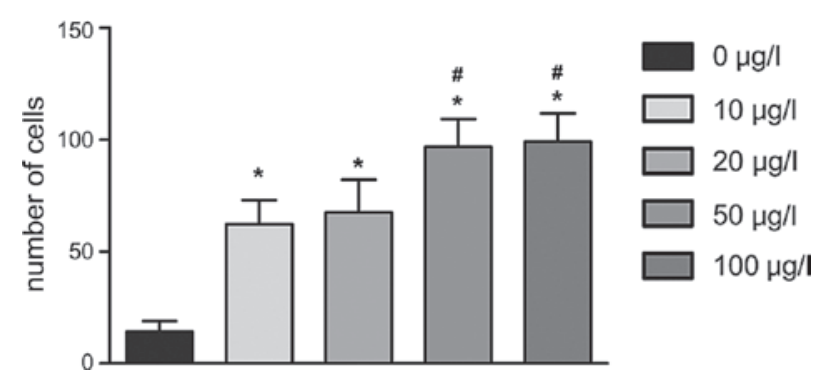

Figure 6. Number of cells transgressed through the Transwell membrane at $24 \mathrm{~h}$ following incubation with interleukin-6 (0, 10, 20, 50 and $100 \mu \mathrm{g} / \mathrm{l})$. Values are expressed as the mean \pm standard deviation $(n=3)$. ${ }^{*} \mathrm{P}<0.05$ vs. $0 \mu \mathrm{g} / 1$; ${ }^{\#} \mathrm{P}<0.05$ vs. 10 and $20 \mu \mathrm{g} / 1$. 
Table II. Relative mRNA and protein expression levels of E-cadherin and vimentin, respectively, in HIBEC lines stimulated with interleukin-6 $(0,10,20,50$ or $100 \mu \mathrm{g} / \mathrm{l})$ for $24 \mathrm{~h}$.

\begin{tabular}{|c|c|c|c|c|c|}
\hline Gene/Protein & $0 \mu \mathrm{g} / 1$ group & $10 \mu \mathrm{g} / 1$ group & $20 \mu \mathrm{g} / 1$ group & $50 \mu \mathrm{g} / 1$ group & $100 \mu \mathrm{g} / 1$ group \\
\hline \multicolumn{6}{|l|}{ Gene } \\
\hline E-cadherin & $1.82 \pm 0.16$ & $0.88 \pm 0.10^{\mathrm{a}}$ & $0.80 \pm 0.09^{\mathrm{a}}$ & $0.40 \pm 0.12^{\mathrm{a}, \mathrm{b}}$ & $0.34 \pm 0.10^{\mathrm{a}, \mathrm{b}}$ \\
\hline Vimentin & $1.01 \pm 0.12$ & $1.36 \pm 0.18^{a}$ & $1.43 \pm 0.15^{\mathrm{a}}$ & $1.78 \pm 0.17^{\mathrm{a}, \mathrm{b}}$ & $1.82 \pm 0.13^{\mathrm{a}, \mathrm{b}}$ \\
\hline \multicolumn{6}{|l|}{ Protein } \\
\hline E-cadherin & $0.76 \pm 0.11$ & $0.74 \pm 0.09$ & $0.71 \pm 0.09$ & $0.33 \pm 0.10^{\mathrm{a}, \mathrm{b}}$ & $0.31 \pm 0.07^{\mathrm{a}, \mathrm{b}}$ \\
\hline Vimentin & $1.78 \pm 0.21$ & $1.86 \pm 0.23$ & $1.89 \pm 0.22$ & $2.36 \pm 0.18^{\mathrm{a}, \mathrm{b}}$ & $2.40 \pm 0.20^{\mathrm{a}, \mathrm{b}}$ \\
\hline
\end{tabular}

Values are expressed as the mean \pm standard deviation $(\mathrm{n}=3) .{ }^{\mathrm{a}} \mathrm{P}<0.05$, vs.0 $\mu \mathrm{g} / \mathrm{l}$; ${ }^{\mathrm{b}} \mathrm{P}<0.05$, vs. 10 and $20 \mu \mathrm{g} / \mathrm{l}$. HIBEC, human intrahepatic biliary epithelial cell.

A

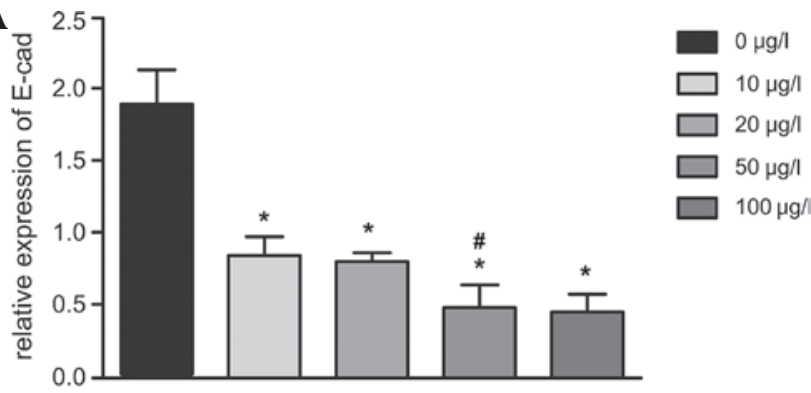

B

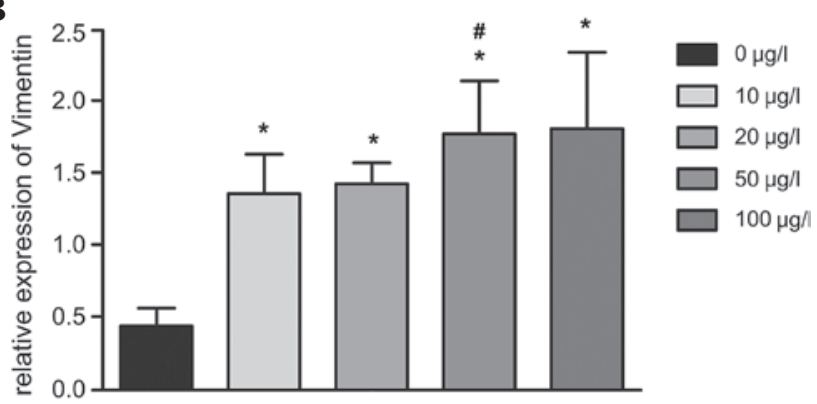

Figure 7. Relative mRNA expression of (A) E-cad and (B) vimentin in the human intrahepatic biliary epithelial cells incubation with interleukin-6 $(0$, $10,20,50$ and $100 \mu \mathrm{g} / \mathrm{l})$ for $24 \mathrm{~h}$ detected by reverse-transcription quantitative polymerase chain reaction analysis. Values are expressed as the mean \pm standard deviation $(\mathrm{n}=3) .{ }^{*} \mathrm{P}<0.05$ vs. $0 \mu \mathrm{g} / 1$; ${ }^{\#} \mathrm{P}<0.05$ vs. $20 \mu \mathrm{g} / 1$. E-cad, E-cadherin.

In analogy with the RT-qPCR results, western blot analysis revealed that the protein expression of E-cadherin in HIBECs was significantly reduced following treatment with IL-6 ( $\mathrm{P}<0.05$ for 50 and 100 vs. 0,10 and $20 \mu \mathrm{g} / \mathrm{l}$ ). In addition, the protein expression of vimentin was significantly increased following treatment with IL-6 $(\mathrm{P}<0.05$ for 50 and 100 vs. 0 , 10 and $20 \mu \mathrm{g} / \mathrm{l}$ ). However, E-cadherin and vimentin expression between the 50 and the $100 \mu \mathrm{g} / 1$ groups as well as between the 0,10 and $20 \mu \mathrm{g} / 1$ groups was not significantly different (all $\mathrm{P}>0.05$ ) (Fig. 8).

\section{Discussion}

Pro-inflammatory cytokine IL-6, produced at low levels by BECs under normal conditions, appears to contribute to biliary
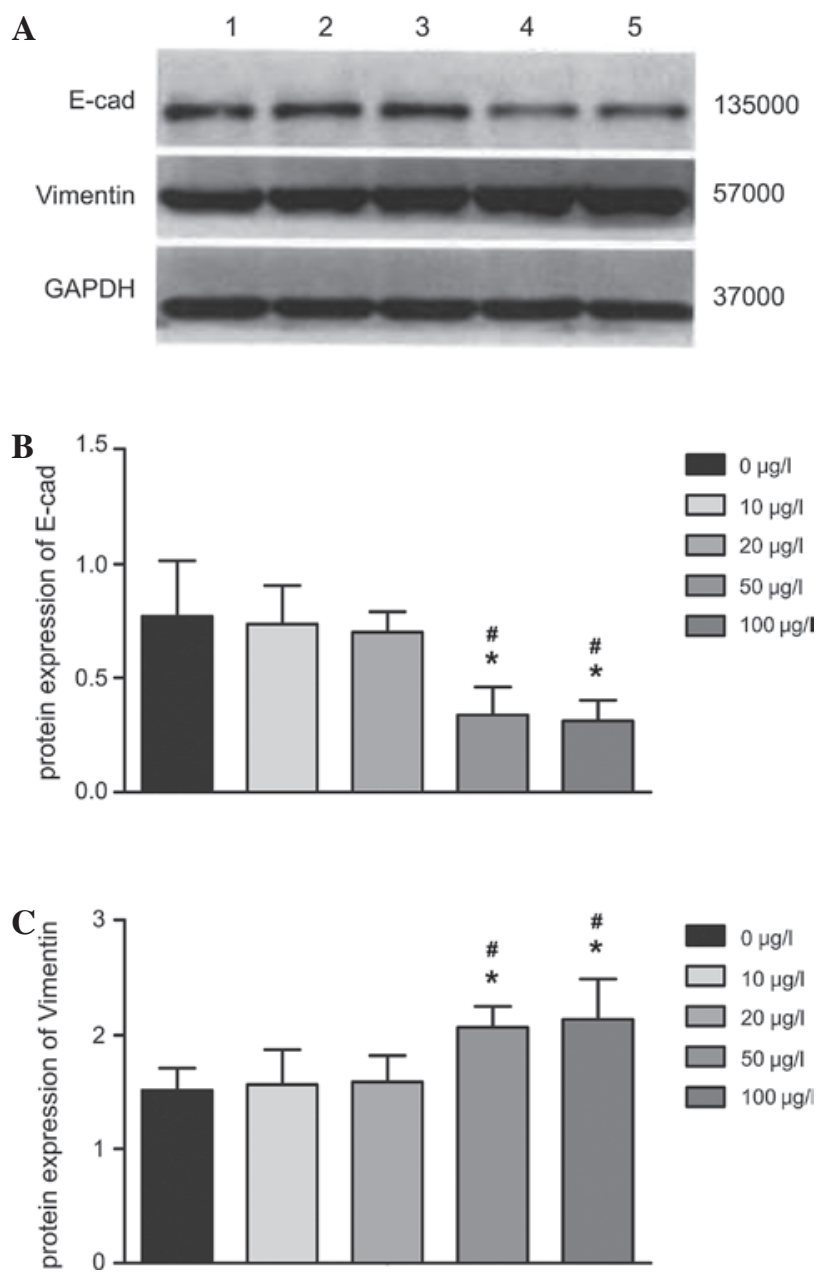

Figure 8. Effects of IL-6 on the protein expression of E-cad and vimentin in human intrahepatic biliary epithelial cells. (A) Representative western blots showing the protein levels of E-cad and vimentin following incubation with IL-6 for $24 \mathrm{~h}$. Lanes, 1, 0; 2, 10; 3, 20; 4, 50; 5, $100 \mu \mathrm{g} / 1 \mathrm{IL}-6$. Densitometric analysis was used for the quantification of the protein expression of (B) E-cad and $(\mathrm{C})$ vimentin. Values are expressed as the mean \pm standard deviation. ${ }^{*} \mathrm{P}<0.05$ vs. $0 \mu \mathrm{g} / 1$.; ${ }^{*} \mathrm{P}<0.05$. vs. 10 and $20 \mu \mathrm{g} / 1$. IL, interleukin; E-cad, E-cadherin.

tree integrity and maintenance of the hepatocyte mass during chronic injury. However, IL-6 levels are elevated in the cytoplasm of pathologic IBECs and IL-6 is also overexpressed at the mRNA level $(11,21-23)$. Exogenous IL-6 showed mitogenic 
activity in BECs; furthermore, IL-6 may regulate trefoil factor family 3 (TFF3) at the mRNA and protein level, contributing to BEC proliferation and migration in mice $(14,24,25)$. The present study revealed an increased migratory and invasive capacity of HIBECs following incubation with IL-6 at various concentrations. Although the exact underlying mechanisms remain to be elucidated, it is likely that IL- 6 activates signaling pathways involved in the regulation of the proliferation and biological behavior of HIBECs $(26,27)$. Consistent with the findings of the present study, a previous study reported that incubation of HIBECs with recombinant IL-6 enhanced their migratory potential, which was indicated to be mediated via activation of the IL-6/signal transducer and activator of transcription (STAT)3/TFF3 signaling pathway (28).

Recent studies have suggested the implication of the EMT in cellular process associated with migration and invasion, and the involvement of certain EMT-associated proteins, including E-cadherin, $\beta$-catenin, adenomatous polyposis coli, S100 calcium-binding protein A4 and vimentin, has been identified (29,30). E-cadherin is a cell-cell adhesion protein for homotypic cell contacts and is a cell-surface marker of epithelial cells. Decreased E-cadherin expression disrupts epithelial integrity and promotes EMT $(31,32)$. Furthermore, increased expression of vimentin is one of the hallmarks of EMT; cellular changes accompanying the EMT include increased vimentin expression and associated changes in cell shape, motility and adhesion (33-35). E-cadherin repression followed by an increase in vimentin expression was observed in human breast cancer cells after IL-6 stimulation, indicating a potential role of IL-6 in the induction of EMT resulting in a mesenchymal phenotype in breast cancer cells $(15,16)$. Of note, the present study showed that incubation of HIBECs with IL-6 at $50 \mu \mathrm{g} / \mathrm{l}$ and above resulted in a significant decrease in mRNA and protein expression of aberrant E-cadherin and a significant increase in vimentin, indicating a significant role of IL-6 in the EMT in the HIBECs. Although the exact underlying mechanisms of the EMT of HIBECs remain to be elucidated, a previous study suggested that IL- 6 stimulation led to EMT-associated changes in E-cadherin and vimentin expression via the Janus kinase/STAT3/SNAIL signaling pathway (17). Consistent with this, morphological changes were observed in HIBECs incubated with IL-6, along with changes in EMT markers and increased invasive behavior.

In conclusion, the present study demonstrated that IL-6 has a significant role in the EMT of HIBECs, as indicated by an increased migratory and invasive capacity of HIBECs, characteristic changes in the aberrant mRNA and protein expression of the EMT markers E-cadherin and vimentin, as well as typical morphological changes indicating a mesenchymal cell type. The present study provided novel insight into pathways which may serve as therapeutic molecular targets for preventing HIBECs from undergoing EMT-associated pathological processes.

\section{Acknowledgements}

The present study was supported by grants from the National Natural Science Foundation of China Youth Science Fund (NSFC; grant no. 81200319) and the NSFC (grant no. 81170426).

\section{References}

1. Yang J and Weinberg RA: Epithelial-mesenchymal transition: At the crossroads of development and tumor metastasis. Dev Cell 14: 818-829, 2008.

2. Cannito S, Novo E, Di Bonzo LV, Busletta C, Colombatto S and Parola M: Epithelial-mesenchymal transition: From molecular mechanisms, redox regulation to implications in human health and disease. Antioxid Redox Signal 12: 1383-1430, 2010.

3. Thiery JP, Acloque H, Huang RY and Nieto MA: Epithelial-mesenchymal transitions in development and disease. Cell 139: 871-890, 2009.

4. Gonzalez DM and Medici D: Signaling mechanisms of the epithelial-mesenchymal transition. Sci Signal 7: re8, 2014.

5. Schulze F, Schardt K, Wedemeyer I, Konze E, Wendland K, Dirsch O, Töx U, Dienes HP and Odenthal M: Epithelial-mesenchymal transition of biliary epithelial cells in advanced liver fibrosis. Verh Dtsch Ges Pathol 91: 250-256, 2007 (In German).

6. Mizuguchi YSS and Isse K: Molecular pathology of liver diseases. Hepatology 59: 1130-1143, 2014.

7. Rodés J, Benhamou JP, Blei A, Reichen J and Rizzetto M: From Basic Science to Clinical Practice. Lacy A and Francis NK (eds). 3rd edition. Wiley-Blackwell, Hoboken, NJ, pp52-57, 2007.

8. Yokoyama T, Komori A, Nakamura M, Takii Y, Kamihira T, Shimoda S, Mori T, Fujiwara S, Koyabu M, Taniguchi K, et al: Human intrahepatic biliary epithelial cells function in innate immunity by producing IL- 6 and IL- 8 via the TLR4-NF-kappaB and -MAPK signaling pathways. Liver Int 26: 467-476, 2006.

9. Karrar A, Broomé U, Södergren T, Jaksch M, Bergquist A Björnstedt $\mathrm{M}$ and Sumitran-Holgersson S: Biliary epithelial cell antibodies link adaptive and innate immune responses in primary sclerosing cholangitis. Gastroenterology 132: 1504-1514, 2007.

10. Kawata K, Kobayashi Y, Gershwin ME and Bowlus CL: The immunophysiology and apoptosis of biliary epithelial cells: Primary biliary cirrhosis and primary sclerosing cholangitis. Clin Rev Allergy Immunol 43: 230-241, 2012.

11. Yasoshima M, Kono N, Sugawara H, Katayanagi K, Harada K and Nakanuma Y: Increased expression of interleukin-6 and tumor necrosis factor-alpha in pathologic biliary epithelial cells: In situ and culture study. Lab Invest 78: 89-100, 1998.

12. Kishimoto T: Interleukin-6: Discovery of a pleiotropic cytokine. Arthritis Res Ther 8 (Suppl 2): S2, 2006.

13. Park J, Tadlock L, Gores GJ and Patel T: Inhibition of interleukin 6-mediated mitogen-activated protein kinase activation attenuates growth of a cholangiocarcinoma cell line. Hepatology 30: 1128-1133, 1999.

14. Yokomuro S, Tsuji H, Lunz JG III, Sakamoto T, Ezure T, Murase N and Demetris AJ: Growth control of human biliary epithelial cells by interleukin 6, hepatocyte growth factor, transforming growth factor betal and activin A: Comparison of a cholangiocarcinoma cell line with primary cultures of non-neoplastic biliary epithelial cells. Hepatology 32: 26-35, 2000.

15. Sullivan NJ, Sasser AK, Axel AE, Vesuna F, Raman V, Ramirez N, Oberyszyn TM and Hall BM: Interleukin-6 induces an epithelial-mesenchymal transition phenotype in human breast cancer cells. Oncogene 28: 2940-2947, 2009.

16. Xie G, Yao Q, Liu Y, Du S, Liu A, Guo Z, Sun A, Ruan J, Chen L, Ye C and Yuan Y: IL-6-induced epithelial-mesenchymal transition promotes the generation of breast cancer stem-like cells analogous to mammosphere cultures. Int J Oncol 40: 1171-1179, 2012.

17. Yadav A, Kumar B, Datta J, Teknos TN and Kumar P: IL-6 promotes head and neck tumor metastasis by inducing epithelial-mesenchymal transition via the JAK-STAT3-SNAIL signaling pathway. Mol Cancer Res 9: 1658-1667, 2011.

18. Colomiere M, Ward AC,Riley C, Trenerry MK, Cameron-Smith D, Findlay J, Ackland L and Ahmed N: Cross talk of signals between EGFR and IL-6R through JAK2/STAT3 mediate epithelial-mesenchymal transition in ovarian carcinomas. Br J Cancer 100: 134-144, 2009.

19. Chun J and Kim YS: Platycodin D inhibits migration, invasion, and growth of MDA-MB-231 human breast cancer cells via suppression of EGFR-mediated Akt and MAPK pathways. Chem Biol Interact 205: 212-221, 2013.

20. Causier B and Davies B: Analysing protein-protein interactions with the yeast two-hybrid system. Plant Mol Biol 50: 855-870, 2002. 
21. Lamireau T, Zoltowska M, Levy E, Yousef I, Rosenbaum J, Tuchweber B and Desmoulière A: Effects of bile acids on biliary epithelial cells: Proliferation, cytotoxicity, and cytokine secretion. Life Sci 72: 1401-1411, 2003.

22. Ezure T, Sakamoto T, Tsuji H, Lunz JG III, Murase N, Fung JJ and Demetris AJ: The development and compensation of biliary cirrhosis in interleukin-6-deficient mice. Am J Pathol 156: 1627-1639, 2000.

23. Liu Z, Sakamoto T, Ezure T, Yokomuro S, Murase N, Michalopoulos G and Demetris AJ: Interleukin-6, hepatocyte growth factor, and their receptors in biliary epithelial cells during a type I ductular reaction in mice: Interactions between the periductal inflammatory and stromal cells and the biliary epithelium. Hepatology 28: 1260-1268, 1998.

24. Yokomuro S, Lunz JG III, Sakamoto T, Ezure T, Murase N and Demetris AJ: The effect of interleukin-6 (IL-6)/gp130 signalling on biliary epithelial cell growth, in vitro. Cytokine 12: 727-730, 2000.

25. Nozaki I, Lunz JG III, Specht S, Park JI, Giraud AS, Murase N and Demetris AJ: Regulation and function of trefoil factor family 3 expression in the biliary tree. Am J Pathol 165: 1907-1920, 2004

26. Chen LP, Cai M, Zhang QH, Li ZL, Qian YY, Bai HW, Wei X, Shi BY and Dong JH: Activation of interleukin-6/STAT3 in rat cholangiocyte proliferation induced by lipopolysaccharide. Dig Dis Sci 54: 547-554, 2009.

27. Chen LP, Qian YY, Li ZL, Bai HW, Cai M and Shi BY: Role of IL-6/STAT3 in rat cholangiocyte proliferation induced by lipopolysaccharide. Zhonghua Gan Zang Bing Za Zhi 17: 374-377, 2009 (In Chinese).
28. Jiang GX, Zhong XY, Cui YF, Liu W, Tai S, Wang ZD, Shi YG, Zhao SY and Li CL: IL-6/STAT3/TFF3 signaling regulates human biliary epithelial cell migration and wound healing in vitro. Mol Biol Rep 37: 3813-3818, 2010.

29. Zeisberg M and Neilson EG: Biomarkers for epithelial-mesenchymal transitions. J Clin Invest 119: 1429-1437, 2009.

30. Kalluri R and Weinberg RA: The basics of epithelial-mesenchymal transition. J Clin Invest 119: 1420-1428, 2009.

31. Kalluri R and Neilson EG: Epithelial-mesenchymal transition and its implications for fibrosis. J Clin Invest 112: 1776-1784, 2003.

32. Huber MA, Kraut N and Beug H: Molecular requirements for epithelial-mesenchymal transition during tumor progression. Curr Opin Cell Biol 17: 548-558, 2005.

33. Kokkinos MI, Wafai R, Wong MK, Newgreen DF, Thompson EW and Waltham M: Vimentin and epithelial-mesenchymal transition in human breast cancer-observations in vitro and in vivo. Cells Tissues Organs 185: 191-203, 2007.

34. Lee JM, Dedhar S, Kalluri R and Thompson EW: The epithelial-mesenchymal transition: New insights in signaling, development, and disease. J Cell Biol 172: 973-981, 2006.

35. Mendez MG, Kojima S and Goldman RD: Vimentin induces changes in cell shape, motility, and adhesion during the epithelial to mesenchymal transition. FASEB J 24: 1838-1851, 2010. 